\title{
MEMORIA DE LA GUERRA CIVIL ESPAÑOLA Y GÉNERO FANTÁSTICO EN EL ESPINAZO DEL DIABLO Y EL LABERINTO DEL FAUNO DE GUILLERMO DEL TORO
}

\author{
José Manuel RUIZ MARTÍNEZ \\ Universidad de Granada \\ jmanuelruiz@ugr.es
}

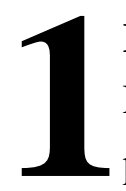

\section{Introducción}

En 2001, el director mexicano Guillermo del Toro, que ya había obtenido cierta notoriedad con películas como Cronos (1993) y Mimic (1997), viene a España a rodar una película producida por los hermanos Almodóvar titulada El espinazo del diablo (2001) ambientada en la Guerra Civil española. Cinco años más tarde, en 2006, tras éxitos en la industria de Hollywood pertenecientes al género fantástico como Blade II (2002) o Hellboy (2004) vuelve a rodar a España, de nuevo con la Guerra Civil como trasfondo -en realidad, la posguerra: la acción se sitúa en el año 1944-, esta vez la aclamada El laberinto del Fauno, ganadora, entre otros premios, del Globo de Oro y el BAFTA a la mejor película de habla no inglesa, y de tres Óscars (mejor fotografía, dirección artística y maquillaje).

El espinazo del diablo y El laberinto del fauno (a partir de ahora ED y LF respectivamente) presentan un planteamiento inédito en relación a su temática: mientras que el acercamiento del cine a la Guerra Civil Española ha sido (tanto en España como fuera de ella) de corte claramente realista o costumbrista -en el sentido convencional que damos a estos términos, esto es: pretendiendo reflejar una época o incluso unos hechos históricos concretos con los que los elementos ficcionales habrán de ser coherentes-, con un marcado tono documental en muchos casos, y casi siempre teñido de una intención política, en las películas de Del Toro, si bien el marco histórico de la trama, su espacio y su tiempo (esto es, la Guerra Civil Española y su posguerra) determina la historia y las acciones de los personajes, el argumento incluye elementos de carácter sobrenatural (la presencia de un fantasma en $E D$, o de seres mitológicos en $L F$ ). Esto hace que puedan percibirse como meras películas «de género» (de género fantástico en este caso), en las que las cuestiones políticas o históricas quedarían muy en segundo plano. El presente texto pretende justamente una reflexión sobre estas dos películas en relación con el problema de la representación ficcional de la Guerra Civil Española en el siglo XXI: ¿Qué aporta este nuevo sesgo de Del Toro a un tema abordado ya muchas veces por el cine español? ¿Convierte a la Guerra Civil Española en un mero marco, intercambiable por otros, para ambientar 
historias de género fantástico? ¿Constituyen estas dos películas la normalización o incluso trivialización de las ficciones basadas en la Guerra Civil Española?

Nuestra hipótesis es que, a pesar del componente sobrenatural, las dos películas de Guillermo del Toro no eluden los problemas ideológicos que, en este caso, plantea el marco histórico donde se ambientan: la Guerra Civil en ellas no es intercambiable por otro conflicto o contexto histórico. En ambas películas, por el contrario, los hechos sobrenaturales cumplen un papel fundamental que acaba por influir en la parte histórica y realista. La ficción, en este caso, ilumina, tematiza y refleja, cabe decir exorciza, algunos de los problemas que ha venido planteando la representación de la Guerra Civil en la literatura y el cine españoles. Y lo hace desde su propia forma, desde el género al que se adscribe, es decir, la ficción de corte fantástico. Podríamos decir que, como sucede según la teoría psicoanalítica con las representaciones que el inconsciente hace de lo reprimido, según explica Bellemin-Noël (2001: 114), «lo que se da a entender, reside sencillamente en la manera transgresora en que se dice». Esto, por otra parte, es algo característico de la ficción en sí, sea o no fantástica: la posibilidad de entender la realidad mediante la creación de una suerte de mundo otro con los mimbres formales del arte. El propio Guillermo del Toro se expresó en términos similares en una entrevista al periódico universitario digital Generación XXI: «Para mí el cine consiste en entender la vida mediante la fabulación. Es la posibilidad de entender más lo que somos, dónde estamos y el porqué» (Freire, 2009). A continuación, vamos a indagar cómo se produce esto tanto en El espinazo del diablo como en El laberinto del Fauno. Pero, para ello, antes se hace precisa una breve aproximación a la teoría de lo fantástico como género narrativo y sus diferencias con lo maravilloso.

\section{El género fantástico y el género maravilloso}

Según David Roas (2001: 9), la condición sine qua non de lo fantástico en una narración es la presencia de un elemento sobrenatural que irrumpe en un contexto o marco realista y cuestiona la estabilidad o predecibilidad de los hechos. El relato fantástico requiere por tanto de la existencia de un orden realista previo que se ve alterado por la aparición súbita de otro orden que irrumpe violentamente. En el relato fantástico, pues, no se produciría tanto la creación de un mundo radicalmente distinto del real cuanto una superposición o choque de planos entre un mundo como el real y un mundo otro, con el consiguiente escándalo de la razón (Campra, 2001: 159-160). El ejemplo por antonomasia de este tipo de choque es el tema del fantasma (Roas, 2001: 8-9): el fantasma aparece como un ser que ha conseguido eludir a la muerte y que vive en un plano distinto de la realidad (en la que vivió), y que, desde dicho plano -que se hallaría fuera del tiempo y el espacio físicos, naturales, pero que tiene sus propias reglas o condiciones de posibilidad-, irrumpe de nuevo en ella, produciéndose la citada superposición o choque de realidades.

Desde un punto de vista estrictamente narrativo, para que esta superposición de realidades sea convincente tienen que darse en el relato unas condiciones muy precisas de verosimilitud. En general se considera, ya desde Aristóteles, que una obra ficticia debe ser verosímil, esto es, narrar hechos que, aunque no hayan sucedido realmente, resulte posible o lógico que sucedan en función de las 
condiciones de posibilidad que el emisor ha creado para su obra. La verosimilitud no depende, pues, de la verdad o la existencia real de lo que se cuenta. Aunque lo real suele tener una verosimilitud intrínseca, fundada en el hecho de ser posible aquello que ha sucedido (Poética, 1451b), no todo lo que puede suceder en la realidad es necesariamente verosímil, pues lo verosímil, según hemos dicho, depende de los elementos de una narración y de su lógica interna. De hecho, como ya señala el propio Aristóteles, hay ocasiones en las que un suceso imposible puede ser más verosímil que un suceso posible (Poética, 1460a). Así, por ejemplo, los sucesos imposibles que se narran en El señor de los anillos -la existencia de la magia o de criaturas como los elfos- resultan verosímiles porque Tolkien ha ido creando un mundo posible, distinto del real, dotado de sus propias características y reglas de funcionamiento, en el que los citados elementos resultan coherentes y necesarios. Sin embargo, un suceso perfectamente posible (por ejemplo, una salvación in extremis), en un determinado contexto de ficción, podría ser inverosímil por constituir una solución excesivamente fácil y ajena a la coherencia interna de la propia narración - lo que se conoce como deus ex machina, o elemento externo que resuelve una historia sin seguir su lógica interna-. En este sentido, la verosimilitud de una narración depende, por una parte, de una suerte de opinión o de sentido común -algo que se percibe como posible en función de unas determinadas condiciones- que varía según las distintas épocas o sociedades, pero también de las convenciones propias de un género o tipo de narración concreto (Campra, 2001: 174): a la ficción realista se le pedirá un tipo de verosimilitud apegado a las condiciones de posibilidad de lo real, y a la ficción fantástica se le pedirá otro tipo de verosimilitud en donde pueda producirse la irrupción de lo imposible (sobrenatural) en el ámbito de lo posible natural o realista. Por tanto en ésta, «la ley del género es la infracción y, por tanto, no es la infracción la que tiene que someterse a la verosimilitud, sino, más bien, las condiciones generales de su realización» (Campra, 2001: 174-175). En lo fantástico, la verosimilitud se crea por convenciones genéricas extrínsecas (paratextos) que crean expectativas al receptor de que, en ese relato en particular, el orden natural va a ser alterado por una presencia sobrenatural; por ejemplo: la cubierta del libro o el cartel de la película. Por otro lado, también se dan una serie convenciones genéricas intrínsecas, aprendidas de relatos del mismo género precedentes: determinados escenarios o protagonistas y, en el caso de las películas, incluso el empleo de una banda sonora inquietante que, en un contexto normal, anuncia la irrupción de lo extraño. En general, el relato fantástico debe cuidar la verosimilitud sobre todo en la coexistencia de ambos planos, el realista y el fantástico, lo que se consigue potenciando la verosimilitud de la parte realista del relato: cuanto más real parezca, más verosímil será su ruptura. Para ello se puede, por una parte, potenciar lo que Barthes denominaba «efecto de realidad», esto es, propiciar la inclusión de pasajes descriptivos o detalles que no aportan nada desde un punto de vista narrativo pero que contribuyen a crear una ilusión de lo real (Campra, 2001: 175); y, por otra, hacer que los personajes de la historia (incluido, en no pocas ocasiones, el propio narrador) duden de los hechos sobrenaturales que se están produciendo hasta que no tienen más remedio que rendirse a la «evidencia», que en este caso es la existencia de fenómenos sobrenaturales. 
Frente al relato fantástico, en el relato denominado maravilloso, del que quizá el mejor exponente son los cuentos de hadas (pero también la llamada -impropiamente, según estamos viendo- «Literatura de fantasía», como la ya mencionada de Tolkien), el marco ficcional ya da cabida a priori a lo maravilloso. No hay superposición de planos, sino un único plano: el de otro mundo distinto del real (si bien puede haber, y de hecho hay, elementos reconocibles de aquél: sería agotador, y quizá imposible, imaginar un mundo absolutamente otro, sin la más mínima traza realista). Lo que sucede en dicho mundo es imposible en el de la realidad, pero, al estar dentro de unas condiciones de posibilidad determinadas de antemano, resulta perfectamente verosímil y asumible por el receptor. Sabemos que en él van a aparecer seres, y a producirse hechos que no tienen cabida en el mundo real, ni siquiera en una representación ficcional verosímil de éste: por ejemplo, los animales van poder hablar y, no sólo eso, sino que los humanos no van a asombrarse de ello, pero precisamente ya contábamos con que eso es justamente lo posible en dicho mundo, que además cuenta con sus propia coherencia: es el beso de una princesa el que hace que una rana vuelva a su ser original de príncipe rompiendo el hechizo, y no el de un labriego, etcétera. Además, en lo maravilloso, más que personajes, existen tipos y situaciones típicas, y las citadas condiciones de posibilidad que determinan la verosimilitud están fuertemente codificadas: esto es lo que le permitió a Propp elucidar una tipología del cuento ruso que es perfectamente extrapolable a los cuentos de otras tradiciones (Propp, 2001). Algunas de estas convenciones del relato maravilloso son: atemporalidad, («hace muchos, muchos años»); ausencia de referentes espaciales («en un lugar muy lejano»); presencia de lo posible junto a lo imposible; o aceptación de lo maravilloso como obvio (Reisz, 2001: 201-202). Estas convenciones tienen, en última instancia, unas implicaciones de carácter moral, relacionadas con una última característica típica del relato maravilloso: el inevitable final feliz. Este, «cumple la función de satisfacer una demanda primordial de justicia, un juicio ético que no se funda en la evaluación de las acciones humanas sino en el sentimiento de que las cosas deberían ocurrir siempre de una cierta manera $-«$ buena», «justa»-, de que el mundo debería ser distinto como es en realidad» (Reisz, 2001: 203) propia de una «moral ingenua» (Reisz, 2001: 203).

Una vez establecida la diferencia entre las ficciones fantásticas y las ficciones maravillosas, estamos en condiciones de afirmar que $E D$ pertenece al género de lo fantástico, y $L F$-con algunos matices que trataremos a continuación- al de lo maravilloso. En el caso de ED, para empezar, el cartel, el tráiler y otras formas de publicidad ya generan en los espectadores la expectativa de hallarse ante una película de género fantástico ${ }^{1}$. Después, en el desarrollo de la trama en sí, se produce tanto la superposición de los dos planos antes descrita, el realista y el sobrenatural, como un esfuerzo por dotar de la máxima verosimilitud al marco realista para que la aparición del fantasma posea también la máxima verosimilitud: la ambientación que -no lo olvidemos- es la del final de la Guerra Civil Española está muy cuidada; los personajes hablan conforme a su época; los propios protagonistas

\footnotetext{
${ }^{1}$ Por ejemplo, en el caso de los carteles, la composición oscura, la casa (el orfanato) al fondo, la presencia misma de la figura distorsionada del fantasma y la tipografía en script, roja, como una pintada de sangre. En el caso del tráiler, aparte de la música con los rasgos propios de las bandas sonoras de terror (golpes, disonancias), nada más empezar el niño protagonista alude a la presencia del fantasma y luego oímos la voz en off de éste pidiendo ayuda.
} 
dudan o niegan lo que están viendo hasta que no les queda más remedio que rendirse a la evidencia; y existen toda una serie de huellas e indicios «empíricos» en el mundo real que la presencia del fantasma deja en él: los objetos que se caen o se rompen, o, el pañuelo ensangrentado del doctor Casares.

Por su parte, $L F$ está ligada a lo maravilloso, pero, como indicábamos, con una peculiaridad importante: la película en sí no pertenece al género maravilloso, sino que incluye en su interior un relato de corte maravilloso. A diferencia del género fantástico (y de $E D$ ), no se da una intersección entre órdenes, con la consiguiente transgresión, sino la inclusión de un orden (el maravilloso) en otro (el realista), sin que confluyan nunca, por lo que la parte maravillosa conserva todas las cualidades inherentes a su género.

Una vez establecida la adscripción genérica de ambas películas, vamos a tratar de verificar nuestra hipótesis: que en $E D$ y $L F$ el problema de la representación de la Guerra Civil Española en relación con la recuperación de la memoria y las consecuencias complejas y traumáticas que aún implica esto en España se refleja desde la propia forma ficcional que ha escogido el director, esto es, los géneros fantástico y maravilloso, y que dichos géneros sirven justamente para tematizar el conflicto en lugar de soslayarlo. Veamos cómo.

\section{El espinazo del diablo y el género fantástico}

El espinazo del diablo transcurre en un orfanato de hijos de republicanos fallecidos en el frente situado en mitad de la meseta castellana durante la Guerra Civil Española. Allí llega Carlos, cuyo padre acaba de morir (aunque él no lo sabe) llevado por su tutor, que lo lleva engañado, sin saber que va a quedarse. El orfanato está regentado por las figuras bondadosas de Carmen y el profesor Casares. Desde el principio, mientras trata de adaptarse al grupo y eludir el acoso del matón del orfanato, Carlos irá percibiendo que en la casa hay una presencia extraña, que los otros también notan pero que pretenden eludir. Esta presencia acabará por revelarse a Carlos como el fantasma de Santi, uno de los niños del orfanato, que desapareció. En realidad, fue asesinado y arrojado a la alberca del sótano por Jacinto, un cuidador, al ser descubierto por el niño en su intento de hacerse con el oro que Carmen custodia para la causa republicana. La noche de la desaparición, por casualidad, había caído una bomba en el patio, que no llegó a explotar y que quedó allí, semienterrada. La desaparición se había explicado como una huida del niño en el pánico del bombardeo; la bomba despierta desde entonces en los niños una fascinación totémica, ya que la relacionan supersticiosamente con la presencia sobrenatural de Santi. Finalmente, Jacinto, en un nuevo intento por hacerse con el oro, provoca (esta vez sí) una explosión en el orfanato que origina una auténtica carnicería, incluyendo la muerte de buena parte de los niños, de Carmen, y que deja muy malherido al profesor Casares, que, sin embargo, espera rifle en mano la vuelta de Jacinto con sus compinches para buscar el oro entre los escombros del edificio. Jacinto vuelve, en efecto, encierra a los niños supervivientes (entre los que se encuentra Carlos), y se hace con el oro, pero los niños consiguen escapar y tenderle una trampa hasta llevarlo a la alberca, donde cae y el peso del oro le impide mantenerse a flote, quedando a merced del fantasma, que encuentra así satisfecha su venganza. En su evasión, los niños cuentan con la ayuda del profesor 
Casares que, aunque en la espera había muerto por las heridas que le produjo la explosión, ha vuelto, también él como fantasma, para ayudarlos.

Este resumen de la trama, aun incompleto por razones de espacio, nos permite no obstante comprender cómo la trama sobrenatural, en colisión con la realista según la convención de lo fantástico, arroja su propio sentido sobre la representación de la Guerra Civil Española. En este caso, la coherencia interna del mundo fantástico que va a irrumpir en el realista queda fundada en el topos genérico de que la injusticia de un asesinato no resuelto puede abrir una brecha en el orden natural, lo que permite la vuelta de la víctima al mundo de los vivos como fantasma hasta que se restablezca el orden perdido. En su comienzo, la película tiene una especie de prólogo: en él oímos una voz en off que dice lo siguiente:

¿Qué es un fantasma? Un evento terrible condenado a repetirse una y otra vez, un instante de dolor quizás, algo muerto que parece por momentos vivo aún, un sentimiento suspendido en el tiempo, como una fotografía borrosa, como un insecto atrapado en ámbar. (Toro, 2001).

Mientras tanto, en prolepsis, se van viendo algunas imágenes de momentos de la película: la bomba que cae y no explota, el fantasma en sí, los fetos conservados en formol que guarda Casares en su gabinete de ciencias, la alberca... Este prólogo constituye una mise en abyme de toda la película: Carlos, el protagonista, tiene que descifrar los motivos de la existencia del fantasma; en este sentido, como indica Irène Bessière (2001: 97), «la entidad tenebrosa que atormenta el relato [fantástico] se presenta como objeto de desciframiento». Y esa misma tarea de desciframiento, al ir encajando los elementos dispersos presentados en el prólogo como respuesta a la pregunta de qué es un fantasma, va a significar la respuesta cabal, descifrada también, a dicha pregunta.

En realidad toda la película constituye una isotopía en torno a la noción de fantasma que se anuncia en el prólogo; al final, fantasma son todos aquellos elementos de la narración que comparten una propiedad fundamental: haber quedado en suspenso, irresueltos: así el fantasma propiamente dicho, cuyo asesinato en vida había quedado oculto; la bomba, cuya razón de ser es estallar y no lo hace $-\mathrm{y}$ por eso los niños, intuitivamente, la identifican con el fantasma de Santi, idea brillante del guión que refuerza la isotopía-; también los fetos que guarda Casares en su gabinete, que no llegaron a nacer, suspendidos en un líquido alcohólico que en la película, significativamente, el doctor explica que se llama limbo; la alberca donde yace el cadáver de Santi, que tiene el mismo color ambarino (el ámbar, la materia donde los insectos quedan atrapados)... Pero fantasma es también el propio doctor Casares, cuya vida ha sido una pura indeterminación: ama a Carmen pero es impotente; apoya la causa republicana, pero no ha sido capaz de defenderla con las armas e, incluso, en una visita al pueblo, niega conocer a unos camaradas a punto de ser fusilados (lo hace junto a un fuego, en una escena que evoca la negación de San Pedro); por último, espera a Jacinto para vengarse, como vigía, con su rifle, pero muere antes de que llegue. Al final, su existencia irresuelta lo transforma, gracias a la convención fantástica, de fantasma metafórico en fantasma literal, que por fin podrá tomar partido: ayudará de forma decisiva, a modo de deus ex machina, a los niños, reparando como muerto lo que no supo defender como vivo. Al final de la película, mientras los niños se marchan del orfanato en ruinas, el 
doctor Casares los contempla alejarse y volvemos a oír la voz en off repitiendo el mismo texto del prólogo; sólo que ahora reconocemos que la voz es la de Casares y, justo al final, se añade: «Un fantasma: eso soy yo» (Toro, 2001).

La clave de la narración fantástica radica en que, al darse la convivencia verosímil de dos órdenes, el natural y el sobrenatural, se produce la aceptación de dicha alteridad. De este modo el fantasma puede operar en el orden natural desde sus facultades sobrenaturales y, por ejemplo, cumplir lo incumplido, clausurar lo inconcluso, todo ello imposible si sólo existiera el orden natural. Por eso para Bessière (2001: 99) el relato fantástico «recoge la obsesión de una legalidad que, a falta de ser natural, puede ser sobrenatural». El relato fantástico se presenta así como la posibilidad de dotar de sentido, de clausura, a un relato que, de pertenecer exclusivamente al orden de lo real, quedaría abierto, irresuelto, clamando justicia (esto es, sentido): como un fantasma. De este modo, lo fantástico «se presenta como un juego pero repone el sentido perdido, el objeto con el que no se sabe qué hacer, sobre otro tablero» (Bessière, 2001: 99).

¿Qué es un fantasma? Esa es la pregunta que articula El espinazo del diablo. Según el Diccionario de psicoanálisis de Laplanche y Pontalis un fantasma es «un argumento imaginario donde el tema está presente y que representa, de forma más o menos deformada por los procesos defensivos, el cumplimiento de un deseo y, en última instancia, de un deseo inconsciente» (Bellemin-Noël, 2001: 113). El espinazo del diablo es un argumento imaginario con presencia de fantasma. En la posibilidad del doctor Casares - personaje caracterizado como un profesor afín a la Institución Libre de Enseñanza, quintaesencia de la República- de restaurar la injusticia del asesinato de los huérfanos (y de su amor, Carmen), y de la destrucción del orfanato bajo la especie del fantasma y asumir por fin el papel de héroe, en la película culmina la idea del fantasma como elemento paradójico que señala la injusticia y posibilita la reparación, pero sólo al precio de hacerlo mediante la transgresión del orden natural. Al producirse durante toda la película un juego especular de fantasmas literales y simbólicos, y una continua isotopía de motivos fantasmales, dar respuesta a la pregunta ¿qué es un fantasma? conduce a la conclusión final de que la propia Guerra Civil, lugar de la acción, es también fantasma, esto es: «Un evento terrible condenado a repetirse una y otra vez, un instante de dolor quizás, algo muerto que parece por momentos vivo aún, un sentimiento suspendido en el tiempo, como una fotografía borrosa, como un insecto atrapado en ámbar.» (El espinazo del diablo). Se trata de una descripción muy precisa para la Guerra Civil en el contexto de la España contemporánea, y de la polémica que este hecho luctuoso aún despierta hoy, más de setenta años después. Si, en palabras de Irène Bèssiere (2001: 84), lo fantástico refleja «bajo el aparente juego de la invención pura, las metamorfosis culturales de la razón y del imaginario colectivo», en El espinazo del diablo, la Guerra Civil Española se muestra como herida abierta, una injusticia por reparar. Mediante la irrupción de lo fantástico, en El espinazo del diablo se señala esta herida, esta ausencia de sentido, pero además se muestra, tematizado, el deseo inconsciente de su reparación, de su clausura con un final apropiado, justo, reparación imposible en la realidad o en la ficción realista, y que sólo podría llevarse a cabo jugando sobre «ese otro tablero», contradictorio y paradójico, de lo fantástico. 


\section{El laberinto del fauno y el género maravilloso}

La acción de El laberinto del fauno se desarrolla pasada ya la Guerra Civil, en 1944, en el norte de España. La niña Ofelia se traslada con su madre, Carmen, a vivir a un caserío en las montañas con su padrastro, el capitán Vidal, del que su madre está embarazada. El capitán está destinado allí para sofocar las revueltas del maquis de la zona. Ofelia es una niña imaginativa, a la que le gusta leer cuentos de hadas. Desde el primer momento, a la niña no le gusta su nuevo padre, un hombre violento y cruel, ni la dependencia de su madre hacia éste. Su único consuelo es la amistad con Mercedes, una criada de la casa que secretamente ayuda al maquis. Una noche, entra en la habitación de la niña un enorme insecto-palo - que ésta ya había visto durante el trayecto hasta el caserío- y que se le revela como un hada. Ésta la conduce hasta un laberinto que hay cercano a la casa, unas antiguas ruinas de apariencia céltica. En ellas la espera una criatura que dice ser un fauno, quien le revela que ella es en realidad la princesa de un mundo subterráneo de ensueño, y que el rey y la reina, su padre y su madre, la esperan desde hace mucho, y que abrieron distintos portales en el mundo humano para que pudiera volver: el laberinto de piedra donde está es uno de ellos. Pero antes de poder volver a su mundo tiene que resolver tres pruebas que demuestren que ella es en realidad la hija perdida. A partir de ese momento, Ofelia vivirá una suerte de doble vida: por una parte, la cotidiana, real, con su padrastro y su madre, en la que el primero va estrechando sin piedad el cerco de los sublevados y mostrando su crueldad y su voluntad de dominio; por otra, la secreta, en donde va resolviendo (no sin problemas ni desobediencias) las pruebas que le impone el fauno. La resolución de las pruebas la va alejando del mundo adulto y la vuelve, a los ojos de sus padres (sobre todo de Vidal), como excéntrica, maleducada y desobediente. Carmen da a luz al hijo de Vidal y muere en el parto. El fauno comunica a la niña que la tercera prueba consiste en tomar a su hermano y llevarlo al centro del laberinto. Ofelia, aprovechando la confusión de un ataque sorpresa del maquis, consigue apoderarse de él y llevarlo allí. Vidal la descubre y la sigue. En el laberinto, el fauno, portando una daga, le dice que le entregue al niño: la última prueba consiste en verter un poco de sangre humana de un inocente para abrir el portal a su reino; el niño no tiene que morir, tan sólo es precisa una poca de su sangre. Sin embargo, Ofelia se niega a que el bebé sufra ningún daño. Llega Vidal (quien no ve al fauno), e insta a Ofelia a que le entregue al niño. Ella se niega y él le dispara, lo toma y se va. Cuando llega al caserío descubre que los rebeldes se han hecho con él y lo esperan. Él, sabedor de que tiene los días contados, le entrega el niño a Mercedes para que lo cuide, y lo ejecutan. Después, ésta corre al laberinto pero encuentra a Ofelia muerta. No obstante, su propia sangre, más su negativa a verter sangre inocente, han culminado con éxito la tercera prueba («habéis elegido bien, Alteza», le dirá después el fauno) y han abierto el portal. Ofelia va a su reino, donde la espera su madre -cuyo rostro es el de su madre real-y su padre, mientras Mercedes sostiene el cuerpo muerto de la niña entre los brazos.

En $E F$, al igual que en el $E D$, hay una especie de prólogo ajeno a la secuencia narrativa convencional de la película. EF comienza con un plano de Ofelia -todavía no sabemos quién es-, tumbada en el suelo; le sangra la nariz. El plano, que está vertical (de modo que la niña parece estar apoyada en una pared), poco a poco va adquiriendo su horizontalidad natural, mientras la sangre vuelve 
a su nariz, como si el metraje fuera hacia atrás. Todo esto nos transmite una profunda sensación de extrañamiento y anuncia -lo comprenderemos mucho después- que toda la película es un flashback, ya que éste es el momento del clímax final en el que Ofelia muere. Entonces la cámara se dirige hacia su ojo hasta obtener un primerísimo primer plano de éste, y funde al comienzo de una narración que, por la imagen previa del ojo, entendemos que sucede en el interior de la cabeza de la niña. Esta narración, en off, es el comienzo ortodoxo de un cuento de hadas:

Cuentan que hace mucho, mucho tiempo, en el reino subterráneo donde no existe la mentira ni el dolor, vivía una princesa que soñaba con el mundo de los humanos. Soñaba con el cielo azul, la brisa suave y el brillante sol. Un día, burlando toda vigilancia, la princesa escapó. Una vez en el exterior, la luz del sol la cegó y borró de su memoria cualquier indicio del pasado. La princesa olvidó quién era, de dónde venía. Su cuerpo sufrió frío, enfermedad y dolor. Y al correr de los años, murió. Sin embargo su padre, el rey, sabía que el alma de la princesa regresaría, quizá en otro cuerpo, en otro tiempo y en otro lugar, y él la esperaría hasta su último aliento, hasta que el mundo dejara de girar... (Toro, 2006a).

Mientras tanto, las imágenes nos van reproduciendo lo que narra la voz, hasta que un fundido nos lleva al «comienzo» propiamente dicho de la película, narrativo, lineal: Ofelia y su madre dentro del coche, camino de su nuevo hogar. La yuxtaposición de planos produce un efecto metonímico inevitable: el espectador entiende que la niña es la princesa que ha regresado en otro cuerpo, otro tiempo y otro lugar. Ofelia va leyendo un cuento de hadas. Hay un plano a una ilustración de éste de una niña rodeada de hadas, que refuerza la idea.

Por eso, aunque en la película parecen convivir dos planos, uno fantástico y otro real, no podemos hablar de una narración propiamente fantástica según se ha definido, ya que ambos planos nunca se tocan. Hay que hablar pues, según hemos indicado más arriba, de una narración maravillosa inserta en otra realista. Si ya el prólogo nos indica que la narración maravillosa - con las características citadas de no lugar y no tiempo, mundos otros, princesas, etc.- se narra en la mente de la niña, luego, durante toda la película, el plano maravilloso siempre aparece cuando la niña se queda sola. Al atender a la planificación, siempre que lo maravilloso parece actuar en el mundo real, el punto de vista es el de Ofelia. Finalmente, cuando Vidal llega al centro del laberinto, en un juego de plano-contraplano, constatamos, como ya hemos dicho, que él no ve al fauno mientras que la niña sí lo ve. Y cuando, cumplida la tercera prueba, la niña alcanza el reino de hadas del que ella es princesa, el rostro de la reina, su madre, según lo ya indicado, es el de su madre verdadera; además, ésta lleva en brazos al niño, cuando el espectador ha visto con total claridad que el niño está en realidad en brazos del miliciano hermano de Mercedes, a quien ésta se lo ha dejado para encontrar a la niña tendida en el suelo, en el centro del laberinto. Todos estos indicios nos conducen a la idea de que el reino subterráneo, el fauno, las tres pruebas, etc., son una fantasía urdida por la niña, lectora compulsiva de cuentos de hadas, para evadirse de una realidad desagradable, en la que siente que incluso su madre parece haberla abandonado. La escena final de su triunfo, que sucede, de hecho, cuando ella está tendida en el suelo, agonizando - es entonces cuando comprendemos que el prólogo es, en realidad, el final- está narrada entre dos fundidos a un dorado brillante -marca convencional en el cine de la presencia de un sueño, una fantasía o un recuerdo-; la película además no concluye en el reino 
maravilloso sino que, tras el segundo fundido, vuelve el plano de la niña muerta y mercedes llorando sobre ella, es decir, la realidad. La escena de la llegada de Ofelia a su mundo como princesa (donde ya no tiene sangre y está ricamente ataviada) podemos interpretarla como su última fantasía, que le proporcionaría un último consuelo a las puertas de la muerte. Ofelia, en conclusión, como una suerte de Don Quijote infantil, es quien ha acabado por confundir el mundo maravilloso de las hadas con la realidad para evadirse de ésta; ha intentado que ambos mundos interactúen, como cuando se lleva al niño al centro del laberinto, pero el mundo real se impone -su padrastro se lo arrebata y la asesina. Insistimos: no hay pues, intersección de planos, sino un cuento maravilloso urdido por la protagonista en su mundo real. Solo que, a diferencia de Don Quijote, la cercanía de la muerte no devuelve a la niña a la realidad, sino que acentúa su evasión hacia el mundo fantástico.

¿Cuál es la función del relato maravilloso? Dado que se produce una yuxtaposición continua entre ambos planos, que no se mezclan, parece darse un interesante efecto metonímico: el plano maravilloso contamina al real y le transfiere parte de su sentido; es un fenómeno análogo al que se produce cuando, tras la narración del comienzo del cuento por la voz en off, pasamos al plano real y esto nos permite comprender que la protagonista es la princesa del cuento. La metonimia, esto es, la traslación de un significado de un término a otro por la relación que tienen de contigüidad, según señala Roger Bozzeto (2001: 228), «permite imponer, sin justificarlas, unas relaciones entre enunciados dispares, al ocultar la incongruencia que debería resultar de ellos». En este caso, la metonimia contamina la historia real con una cierta aura de cuento de hadas; los personajes buenos adquieren la categoría de tipos característicos de cuentos de hadas similares a los que ya señaló Propp (vid. 2001): el hermano de Mercedes es el héroe; la propia Mercedes es el donante (ayudante) del héroe; la llave de la despensa es el objeto mágico; y, por supuesto, Vidal es el agresor por antonomasia, «el malo», el monstruo, un verdadero ogro sin piedad. Pero, al mismo tiempo, operando en unas coordenadas ideológicas más sutiles, la historia «real», planteada ya de por sí en unos términos un tanto inverosímiles, por efecto de la presencia de la historia maravillosa, se tiñe al mismo tiempo de verosimilitud, esto es, de realismo. Gracias a la historia maravillosa, la sospecha de un planteamiento excesivamente maniqueo de la historia realista, con un capitán fascista de un sadismo infinito y unos rebeldes absolutamente bondadosos, heroicos y abnegados, que además -y esto es lo más importantetriunfan al final sobre el mal y lo derrotan (lo que difícilmente pudo ocurrir en la Historia con mayúscula), se diluye, y aquélla adquiere consistencia. La historia que, planteada como una visión realista y memorialista de la posguerra española y la represión franquista, hubiera sido tachada de excesivamente ingenua (un sesgo frecuente en la ficción sobre la Guerra Civil española en la actualidad), yuxtapuesta a un cuento maravilloso, gracias al «abuso de autoridad» que supone la «estrategia metonímica» (Bozzeto, 2001: 218), se dota por contraste de un aura de realismo. La presencia de lo maravilloso refuerza una determinada visión de la Historia que la acerca a lo que debería haber sido, al margen de si lo fue o no ${ }^{2}$. ${ }^{2}$ La visión de la Guerra Civil Española en $E F$, cuya verosimilitud se sustenta en buena medida, según decimos, en la lógica
del cuento de hadas, con un planteamiento claramente ingenuo y maniqueo, contrasta de forma muy interesante con unas 
Por último, aun cuando los dos planos, el realista y el maravilloso, no se toquen jamás, lo cierto es que la creencia de la niña en el segundo, acaba influyendo en su comportamiento en el primero -es decir, en su vida real, cotidiana-, y modificando efectivamente la realidad: Ofelia, al conseguir llevarse al niño para cumplir la tercera prueba, propicia que Vidal, obsesionado con su hijo, en quien ve una continuación de sí mismo, descuide el mando en plena crisis por ir tras él, lo que acaba siento determinante en la victoria de los rebeldes (esta idea aparece reflejada explícitamente en las notas de trabajo del director [Toro, 2006b]). Por eso aunque el plano final no es el del reino maravilloso, sino el de Ofelia muerta, su decisión de no entregar al niño al fauno, que no es sino la de que el fin no justifica los medios, esto es, lo opuesto a lo que hace Vidal (y el fascismo, del que es sinécdoque), su sangre de víctima, derramada en el mundo real y por una causalidad real, parecen abrir efectivamente la puerta a los dos mundos y conectarlos, permitiendo que la bondad del uno permee el otro. De nuevo la voz en off lo explica tras el plano de la protagonista muerta, cerrando el cuento maravilloso que inició al principio de la película:

Y se dice que la princesa descendió al reino de su padre y que ahí reinó con justicia y bondad por muchos siglos, que fue amada por sus súbditos y que dejó detrás de sí pequeñas huellas de su paso por el mundo, visibles sólo para aquel que sepa dónde mirar... (Toro, 2006a).

Mientras tanto, vemos la imagen de un árbol muerto cercano al caserío -que cumplía un papel concreto en la trama maravillosa-, que, como el olmo de Machado, ha florecido. Es decir: la fe y la decisión moral de la protagonista, su sacrificio final, aun motivados por una trama maravillosa ajena al mundo real, puede acabar por modificar éste, aunque, en apariencia, el mal haya triunfado. Es el poder de la ficción de modificar la realidad.

\section{Conclusiones}

En conclusión, la relación entre ficción y realidad en las películas de Guillermo del Toro dedicadas a la Guerra Civil española y su posguerra parece ser la de buscar y tematizar, a través de lo fantástico y lo maravilloso (en definitiva, de la ficción en sus planteamientos más evidentes), un sentido, una clausura e, incluso, una reparación a unos hechos traumáticos que, en cuanto Historia, carecen de dicha posibilidad de clausura y sentido y que, por ser lo que fueron y no lo que debieron ser-definición aristotélica de la Historia-, han quedado como una herida abierta en el sentido. En ED, la tematización de esta falla se produce mediante el recurso a lo fantástico, que, convocado por la injusticia misma, irrumpe en el plano realista con su propia lógica causal, y que, desde la autonomía de ésta, permite una reparación de lo irreparable en dicho plano real, aun cuando implique una transgresión de sus reglas (pero es una transgresión cuya verosimilitud es aceptada por el espectador en función de unas convenciones genéricas, propias de lo fantástico, que se respetan, según hemos

declaraciones de Guillermo de Toro sobre la misma, que parecen hacerlo consciente de esta cuestión y de su relación fundamental con su película: «Creo que es una guerra que en la imaginación de muchos escritores se ha vuelto muy romántica, muy blanco y negro, un poco la última guerra entre el Bien y el Mal, o la Derecha y la Izquierda. No es así, es una guerra infinitamente más compleja, evidentemente, y no hay tal cosa como un blanco y negro» (El laberinto del fauno detrás de las cámaras. Dir., Guillermo del Toro. Prod. y ed. Miguel Torresblanco. 2006. DVD.). 
expuesto). En $E F$ se consigue un efecto análogo mediante el elemento maravilloso el cual, aun cuando no irrumpe en el plano realista, cumple una doble función: por una parte, dota de verosimilitud por contraste a la representación ficcional de la realidad representada en la película, acercándola a lo que debió ser (con el triunfo del maquis) en lugar de a lo que fue; por otro, al final, abre la posibilidad de que la justicia propia de los cuentos de hadas contamine por metonimia al plano realista y permita en él el final feliz característico de estos, aun cuando la protagonista haya muerto. Que la fe en la ficción que tiene Ofelia posibilite que la moral propia de lo maravilloso ${ }^{3}$ acabe por transferirse al plano de lo real, aunque sea al menos para quien «sabe dónde mirar».

\section{Bibliografía}

Alsina, José, ed. (1994): Aristóteles, Poética. Trad. de José Alsina. Barcelona, Bosch.

BELLEMIN-NoËL, Jean (2001): «Notas sobre lo fantástico», en D. ROAS, ed., Teorías de lo fantástico, Madrid, Arco Libros, pp. 107-140.

BESSIÈRE, Irène (2001): «El relato fantástico: forma mixta de caso y adivinanza», en D. ROAS, ed., Teorías de lo fantástico, Madrid, Arco Libros, pp. 83-104.

CAMPRA, Rosalba (2001): «Lo fantástico: una isotopía de la transgresión», en D. ROAS, ed., Teorías de lo fantástico, Madrid, Arco Libros, pp. 153-192.

FREIRE, Enrique, y Frank G. RUBIO (2009): «Entrevista a Guillermo del Toro», en Generación XXI, 3 de junio. Sugerencia Editorial S. L., p. 15.

PROPP, Vladimir (2001): Morfología del cuento. Madrid, Akal.

ROAS, David (2001): «La amenaza de lo fantástico», en D. ROAS, ed., Teorías de lo fantástico, Madrid, Arco Libros, pp. 7-44.

ToRo, Guillermo del, dir. (2001): El espinazo del diablo [película]. España: El Deseo.

—, dir. (2006a): El laberinto del fauno [película]. España: Estudios Picasso.

(2006b): El laberinto del fauno. Guión cinematográfico. Madrid, Ocho y Medio.

\footnotetext{
${ }^{3}$ Como ya indicamos, «el sentimiento de que las cosas deberían ocurrir siempre de una cierta manera -«buena», «justa»-, de que el mundo debería ser distinto como es de realidad» (Reisz, 2001: 203)
} 